\section{Immunological individualism}

\author{
C.A. Janeway, Jr
}

Idiotypes and Lymphocytes. By Constantin A. Bona. Pp.211. ISBN 0-12-112950-0. (Academic: 1982.) £18.60, $\$ 28$.

IDIOTYPES, which are antigenic determinants unique to antibody molecules binding a particular antigen, have been a central interest of immunologists in recent years. Initial studies defined idiotypic determinants immunochemically, and demonstrated that certain idiotypic determinants could be used to map genes required for idiotype expression in induced antibody responses. These studies showed that some idiotypic determinants behaved as though they were products of germ line genes encoding immunoglobulin heavy and/or light chain variable regions, consistent with the location of these markers.

A second focus has been the use of antiidiotypic antibodies to probe the nature of lymphocyte receptors for antigen. The precise meaning of such studies is still disputed, but they do support the structural similarity of $\mathrm{T}$ and $\mathrm{B}$ lymphocyte receptors specific for the same antigen.

Perhaps the most active area of research involving immunoglobulin idiotypes was launched by a theoretical paper published in 1974 by Niels Jerne, in which the immune system was described as a network of interacting idiotypes. The basic premise of the network theory is that immunoglobulins and $\mathrm{T}$ cell receptors, since they can specifically recognize virtually any foreign protein, must themselves be as structurally and antigenically diverse as the universe of external or foreign antigens.

It follows from this premise that any foreign antigenic determinant will be mimicked by an internal image antigenic determinant found in the variable domains of an animal's own immunoglobulins and $T$ cell receptors. Furthermore, antibody produced in response to the foreign antigen will also bind to, or be bound by, this internal image set of immunoglobulins and receptors. The circular nature of this interaction has made it difficult to assess its influence on an antibody response, but numerous artificial experiments involving the direct injection of idiotype or antiidiotype do suggest that such interactions can affect the expression of idiotype itself.

Because of the extensive interest in idiotypy, it would be very helpful to have a current and thorough review of the field, citing major principles and the data that

\section{Evolution from space}

Americans now have the opportunity to read Fred Hoyle and Chandra Wickramasinghe's Evolution from Space. The book (which was reviewed in Nature 294, 489; 1981) has been published in the United States by Simon \& Schuster, price $\$ 13.95$. Medicine. support them. Unfortunately, Dr Bona has not provided us with such a book. This monograph, though appropriately brief, consists of a good deal of loosely organized data and very little in the way of an enlightening overview. This failing is seen most clearly in the tables and figures, which consist of raw data from Bona's own work. Bona's contributions to this field have indeed been numerous, but valuable data from other laboratories are given short shrift, while those from his own laboratory are presented in detail but without the necessary supporting text, making them virtually impossible to decipher without carefully scrutinizing each table. This greatly weakens the value of the book, as well as using a great deal of space. Furthermore, citations of other authors' research are not very accurate, and, since they are not supported by actual data, the reader seeking information about work by other investigators cannot rely on the text as a source.

This book covers an area of great current interest. But because of its lack of clarity and balance in presentation it can be recommended neither as an introduction to the field nor as a comprehensive treatise intended for the expert.

C.A. Janeway, Jr is Associate Professor of Pathology at Yale University School of

\section{Cell meets cell}

\section{David I. Gottlieb}

Cell Behaviour: A Tribute to Michael Abercrombie. Edited by Ruth Bellairs, Adam Curtis and Graham Dunn. Pp.615. ISBN 0-521-24107-3. (Cambridge University Press: 1982.) $£ 45, \$ 89.50$.

PrOFESSOR Michael Abercrombie was a pioneer in the study of how vertebrate cells move and respond to each other's presence. That line of inquiry has since broadened into a vigorous branch of cell biology which is a major part of contemporary science. As a memorial to the man and his accomplishments, a group of his friends and colleagues have assembled this collection of essays. They have succeeded in both honouring their friend's memory and producing a volume which will be of great use to other scientists.

The book consists of a posthumous review of cell motility by Professor Abercrombie, 22 scientific essays on related topics and a personal memoir of Michael Abercrombie by D. R. Newth.
More Random Walks in Science

\section{Compiled by \\ Robert L Weber}

Another inspired collection from Robert Weber in the same entertaining vein as his outstandingly popular A Random Walk in Science!

This new anthology offers yet more fascinating and frequently amusing anecdotes, quotations, illustrations, articles, and reviews which reflect, individually and together, the more lighthearted aspects of the scientific world, and the less serious excursiuns of the scientific mind. Too often, scientists are taken for men whose intelligence is of a ponderous kind, but Dr Weber, who believes that science should be entertaining as well as enlightening, demonstrates that their humour and wit is never far from the surface, and yet is tempered by wisdom and keen intellect. His anthologies are guaranteed to delight anyone who has a professional or amateur interest in science, and many more besides who do not

October 1982 xvi $+208 p p$ illus hardcover $\quad 0-85498-040-7 \quad £ 9.95$

Still available, Dr Weber's earlier and ever popular

A Random Walk in Science

a magnificent assemblage of in formal writings, comment and historical record. There is not a dull page; wit and stimulation abound.

Times Educational Supplement

1973 xvii $+206 p p$ illus hardcover $0-85498-027-X \quad £ 7.95$

Published by The Institute of Physics and distributed by Adam Hilger Ltd.

Adam Hilger Ltd

Techno House Redcliffe Way Bristol BS1 6NX England 